\title{
Correction to: Photocatalytic Degradation of Methylene Blue, Rhodamine-B, and Malachite Green by Ag @ $\mathrm{ZnO} / \mathrm{TiO}_{2}$
}

\author{
Süleyman Kerli ${ }^{1} \cdot$ Mustafa Kavgacı $^{2}$ - Ali Kemal Soğuksu ${ }^{3} \cdot$ Barış Avar $^{4}$
}

Published online: 23 December 2021

(c) The Author(s) under exclusive licence to Sociedade Brasileira de Física 2021

Correction to: Brazilian Journal of Physics

https://doi.org/10.1007/s13538-021-01007-1

The authors' affiliations are correct are shown here. The original article was corrected.

Publisher's Note Springer Nature remains neutral with regard to jurisdictional claims in published maps and institutional affiliations.

The original article can be found online at https://doi.org/10.1007/ s13538-021-01007-1.

Ali Kemal Soğuksu

kemalsoguksu@gmail.com

1 Department of Energy Systems Engineering,

Kahramanmaraş İstiklal University, Kahramanmaraş 46100,

Turkey

2 Department of Opticianry, Elbistan Vocational School of Health Services, Kahramanmaraş İstiklal University, Kahramanmaraş, Turkey

3 Kahramanmaraş Science and, Arts Center, Kahramanmaraş 46100, Turkey

4 Department of Metallurgical and Materials Engineering, Zonguldak Bülent Ecevit University, Zonguldak 67100, Turkey 